\title{
Expanding the Phenotype of TRMT10A Mutations: Case Report and a Review of the Existing Cases
}

\author{
(1) Zeynep Şıklar ${ }^{1}$, (1) Tuğba Kontbay ${ }^{1}$, (1) Kevin Colclough ${ }^{2}$, (1) Kashyap A. Patel3 , (1) Merih Berberoğlu1 \\ ${ }^{1}$ Ankara University Faculty of Medicine, Department of Pediatric Endocrinology, Ankara, Turkey \\ 2Exeter Genomics Laboratory, Royal Devon and Exeter Hospital, Exeter, UK \\ 3 University of Exeter, College of Medicine and Health, Exeter, UK
}

What is already known on this topic?

The mutation of the tRNA methyltransferase 10 homologue A (TRMT10A) gene causes a novel recessive syndrome of abnormal glucose homeostasis associated with distinctive features. A few cases have been reported to date.

\section{What this study adds?}

Ovarian failure with small ovaries, high gonadotropins and low anti-Mullerian hormone levels can lead to pubertal delay in these patients. Growth hormone deficiency can be an additional finding of this syndrome.

\begin{abstract}
The tRNA methyltransferase 10 homologue A (TRMT10A) gene encodes tRNA methyl transferase, and biallelic loss of function mutations cause a recessive syndrome of intellectual disability, microcephaly, short stature and diabetes. A case with intellectual disability and distinctive features including microcephaly was admitted. She was diagnosed with epilepsy at 2.5 years old. At 3.6 years of age, severe short stature related to growth hormone $(\mathrm{GH})$ deficiency was detected. She had an incidental diagnosis of diabetes at age 11.4 years which was negative for diabetes antibodies with persistent C-peptide level and she was treated with metformin. Spontaneous puberty did not begin until 15.7 years of age and she was found to have primary ovarian failure. A homozygous p.Arg $127^{*}$ mutation in TRMT10A was detected. In addition to the typical clinical features which characterize TRMT10A syndrome, we observed an unusual form of impaired glucose metabolism which presented in early childhood with hypoglycemia followed by diabetes in late childhood. GH deficiency and primary ovarian failure may also be additional findings of this syndrome. Patients with slow onset diabetes who are negative for autoantibodies and have extra-pancreatic features should be tested for all known subtypes of monogenic diabetes.
\end{abstract}

Keywords: TRMT10A, monogenic diabetes, ovarian failure

\section{Introduction}

Human glucose metabolism can be disrupted by pathogenic mutations in numerous genes with some of them associated with distinctive clinical and laboratory features (1). Recently, a novel syndrome has been reported characterized by abnormal glucose homeostasis or non-autoimmune diabetes associated with microcephaly, epilepsy, intellectual disability, failure to thrive and delayed puberty due to biallelic pathogenic mutations in the tRNA methyltransferase 10 homologue A (TRMT10A) gene $(2,3,4,5,6)$.

tRNAs are non-coding RNA molecules essential for protein synthesis. They are crucial for cellular function and can undergo modifications of their bases and sugar moieties. Reduced modifications may lead to tRNA degradation or fragmentation. TRMT10A is a tRNA modifying nuclear enzyme with methyl transferase activity and it is localized in the nucleolus where tRNA modifications occur. TRMT10A 
deficiency induces oxidative stress and initiates the apoptosis of beta cells (7).

Although short stature and delayed puberty in addition to disturbed glucose metabolism have been reported in those patients with TRMT10A deficiency, growth hormone (GH)-insulin-like growth factor-1 (IGF-1) axis has not been evaluated in the patients reported; except for one (8). We report on a patient with GH deficiency, ovarian failure, nonautoimmune diabetes and a homozygous mutation in the TRMT10A gene. Additionally, a review was undertaken of any existing cases for further evaluation.

\section{Case Report}

The patient was the second child born to non-consanguineous parents. The pregnancy was uneventful with the child being born at term without immediate postnatal problems. The child's birth weight was 2,100 g (z-score: -3.03) and she had microcephaly (head circumference: $30 \mathrm{~cm},<3^{\text {rd }}$ centile). She was found to have difficulty in feeding during the first two years of life and was underweight (her weight was $8.8 \mathrm{~kg}$ at 2 years old, her z-score was -2.39). Later, she was diagnosed with delayed neuromotor development with mild intellectual disability (24 months walking, 36 months speech). This was followed by epilepsy diagnosed at 2.5 years old which was being treated with valproic acid at the time of writing. On cranial magnetic resonance imaging (MRI), a small pituitary (3 $\mathrm{mm}$ in length) with normal structure and an anterior arachnoid cyst $(3.5 \times 2 \mathrm{~cm})$ of the left temporal lobe were detected.

Informed consent both for publication of this case report and for molecular analyses were given by the parents of the patient.

Growth and puberty of the patient: She was referred to the pediatric endocrinology clinic at 3.6 years of age for short stature. Her height was $84 \mathrm{~cm}$ [standard deviation score (SDS): -3.7], her weight was $11.4 \mathrm{~kg}$ (SDS: -2.22), her head circumference was $45 \mathrm{~cm}$ (SDS: -3.2) and her bone age was 2.5 years. Her mid-parental height was $153.2 \mathrm{~cm}(-1.14$ SDS). Clinical examination revealed distinctive features including microcephaly, a small face and deep-set eyes.

On laboratory examination; complete blood counts, electrolytes, liver enzymes, renal function tests, thyroid function tests [thyroid stimulating hormone: $4.75 \mu \mathrm{mIU} / \mathrm{mL}$ (N: 0.4-5.3), free T4: 12,1 pmol/L (N: 7-16 pmol/L), prolactin level [14.2 ng/mL ( $\mathrm{N}: 4-20 \mathrm{ng} / \mathrm{mL})$ ], urine and blood amino acid level results were normal. Polyuria was not observed, and urine specific gravity was 1.018. Celiac antibodies were negative and the karyotype was 46, XX. Her brainstem auditory evoked response test was also normal.
Serum IGF-1 and IGF-binding protein 3 levels were low (40.9 $\mathrm{ng} / \mathrm{mL}$, SDS: -1.44 and 2,550 $\mathrm{ng} / \mathrm{mL}$, SDS: -2.31 , respectively). GH stimulation tests (L-Dopa and insulin tolerance tests) were consistent with $\mathrm{GH}$ deficiency (peak $\mathrm{GH}$ levels were $6.1 \mathrm{ng} / \mathrm{mL}$ in the L-Dopa test and $3.3 \mathrm{ng} /$ $\mathrm{mL}$ in the insulin tolerance test) (9). Growth velocity was low during follow-up. At 5.4 years of age, her height SDS decreased to -4.38 .

At that time, recombinant human $\mathrm{GH}$ (rhGH) therapy was initiated at a dose of $0.28 \mathrm{mg} / \mathrm{kg} /$ week. Growth velocity increased from $4 \mathrm{~cm} / y e a r$ to $8 \mathrm{~cm} /$ year after the first year of $\mathrm{GH}$ therapy. At the second year of treatment, growth velocity decreased, and the dose of GH was increased to $0.35 \mathrm{mg} / \mathrm{kg} /$ week (Figure 1). IGF-1 levels often remained within normal ranges with GH treatment (annual IGF-1 levels were 117.1, $223,254,441,327,425,254$ and $234.6 \mathrm{ng} / \mathrm{mL}$ ). GH could be maintained until the age of 14.7 years. Her compliance with GH treatment was low and the parents of the patient did not accept further GH treatment. At the cessation of hGH therapy, her achieved height was $142 \mathrm{~cm}$, height-SDS: -3.3 (mid-parent height $153.2 \mathrm{~cm}$ ) (Figure 1).

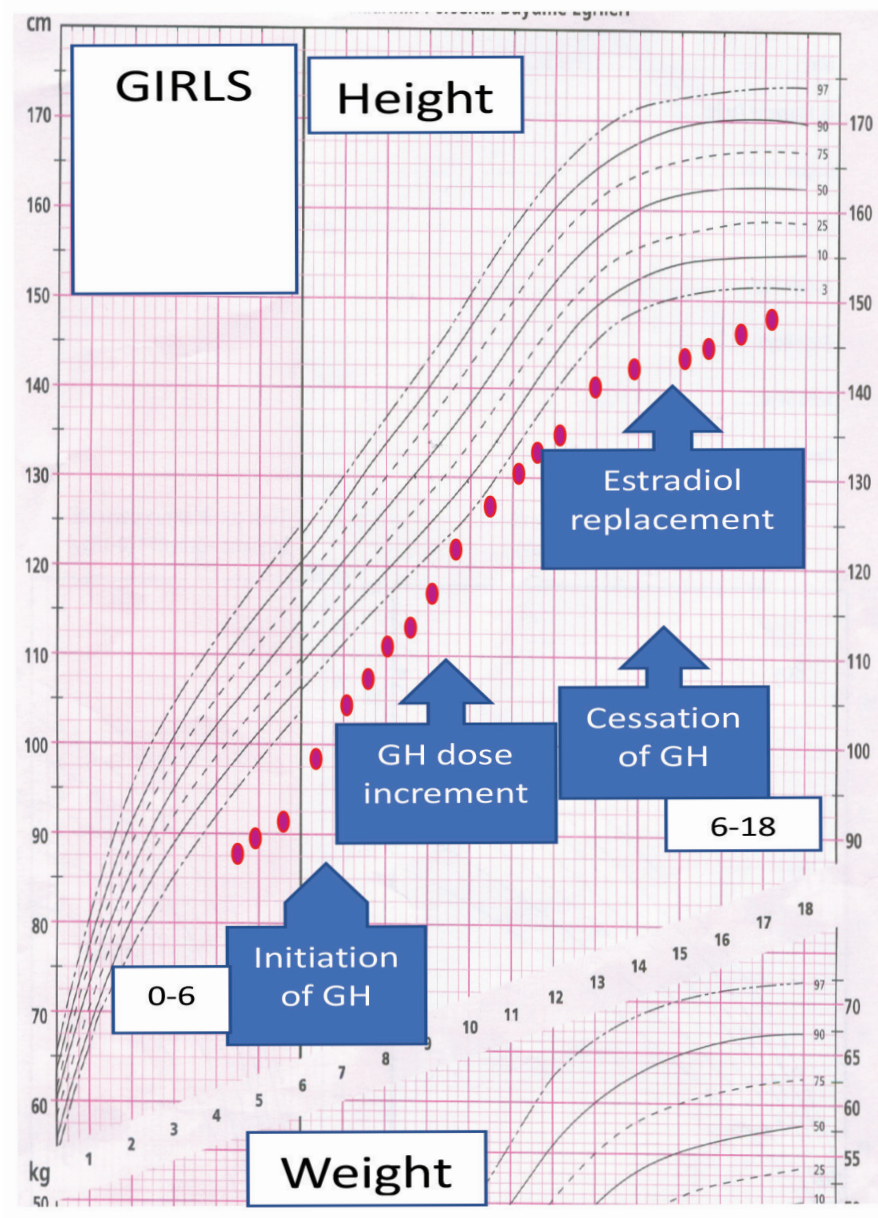

Figure 1. Growth chart of the patient 
At age 13 years, she was still pre-pubertal and her bone age was 12 years. Basal luteinizing hormone (LH) levels $(0.12 \mathrm{mIU} / \mathrm{mL})$, estradiol $(0.12 \mathrm{pg} / \mathrm{mL})$ and $\mathrm{LH}$ response to LH-releasing hormone stimulation test $(4.42 \mathrm{mIU} / \mathrm{mL})$ were pre-pubertal. However, basal and stimulated follicle stimulating hormone (FSH) were $6.48 \mathrm{mIU} / \mathrm{mL}$ and 24.85 $\mathrm{mIU} / \mathrm{mL}$, respectively. A transabdominal pelvic ultrasound study showed that her small uterine volume $\left(1.6 \mathrm{~cm}^{3}\right)$ and ovarian volumes were as low as $0.12 \mathrm{~mL}$ (right) and $0.06 \mathrm{~mL}$ (left). In both ovaries, follicles were not detected. Although it was decided to start pubertal induction, the parents did not give estrogen replacement therapy until 15.7 years of age. At this time, the following results were obtained: height: 145 cm (SDS: -2.95), weight: $35.8 \mathrm{~kg}$ (z-sore: -3.87), body mass index (BMI): $17.3 \mathrm{~kg} / \mathrm{m}^{2}$ (z-score: -2.2 ), relative BMI: $80 \%$, puberty stage: still Tanner 1 and bone age: 13.5 years. Low estradiol ( $<10 \mathrm{pg} / \mathrm{mL}$ ), high basal LH $(9.5 \mathrm{mIU} / \mathrm{mL})$ and FSH (18.4 $\mathrm{mIU} / \mathrm{mL})$ were consistent with hypergonadotropic hypogonadism. Her serum anti-Mullerian hormone (AMH) level was found to be $0.07 \mathrm{pmol} / \mathrm{L}(\mathrm{N}: 3.1-17.8 \mathrm{pmol} / \mathrm{L})$. The small ovaries, high gonadotropins and low AMH levels were consistent with ovarian failure. After convincing the family, the patient was started with estradiol (Estrofem) ${ }^{\circledR} 2$ mg tablets, $1 / 8$ of a tablet once a day. It was aimed to switch to cyclic treatment within 2 years by increasing the dose at 6-month intervals. At the age of 17.5, she reached Tanner stage 3 puberty and her height was $149.8 \mathrm{~cm}$ (Table 1).

Glucose metabolism of the patient: At 4 years of age, on routine blood testing during a check-up at a pediatric neurology clinic, fasting blood glucose (FBG) was detected as 34 and $39 \mathrm{mg} / \mathrm{dL}$, while fasting insulin was $2.1 \mathrm{IU} / \mathrm{mL}$ at a second blood glucose (BG) measurement. FBG was also low at $\mathrm{GH}$ stimulation test $(35 \mathrm{mg} / \mathrm{dL})$. Adrenocorticotropic hormone and cortisol levels were normal and ketones were negative when hypoglycemia occurred. The patient was asymptomatic during the test and remained so thereafter with no symptomatic episodes of hypoglycaemia.

She had an incidental diagnosis of diabetes at age 11.4 years. On routine examination, FBG levels were found to be $136 \mathrm{mg} / \mathrm{dL}$. She was asymptomatic, without polyuria or polydipsia. Her oral glucose tolerance test (OGTT) results indicated diabetes (Table 1).

Hemoglobin A1c (HbA1c) at diagnosis was $7.4 \%$. She tested negative for islet cell, anti-GAD and anti-insulin antibodies, while her C-peptide level was $1.29 \mathrm{ng} / \mathrm{mL}$ (N: 1.1-4.4), her insulin level was $7.2 \mathrm{mIU} / \mathrm{mL}$ (N: 4-16), and her BG level was $240 \mathrm{mg} / \mathrm{dL}$. Her BMI z-score was -2.1. She was treated with metformin from the time of her diagnosis. As her C-peptide level was not low, metformin treatment was started at $2 \times 500$ $\mathrm{mg}$ daily. In the follow-up, it was increased to $1,500 \mathrm{mg} /$ day. No side effects were observed. Her last HbA1c at age 17.1 years was $6.4 \%$ on $1.500 \mathrm{mg} /$ day metformin.

Genetic analysis of our case: Sequencing analysis of all known monogenic diabetes genes by targeted next generation sequencing was undertaken as part of the Genetics of Early Onset Diabetes Study (GOOD study). The GOOD study is a cross sectional multi-center clinic-based study which aims to identify novel genetic subtypes of monogenic diabetes by excluding type 1 diabetes using a polygenic risk scores. The recruited patients undergo sequencing analysis of the known monogenic diabetes genes first, and those patients with negative tests are further investigated by whole-genome-sequencing in order to find novel genetic etiologies.

A homozygous nonsense mutation in TRMT10A (c.379C > T, p.Arg $127^{*}$ ) was identified. This mutation has been reported previously in a patient with TRMT10A syndrome (2) and,

\begin{tabular}{|c|c|c|c|c|c|}
\hline & On admission & On GH initiation & On metformin initiation & $\begin{array}{l}\text { On estrogen } \\
\text { initiation }\end{array}$ & On last examination \\
\hline Age (year) & 3.6 & 5.4 & 11.4 & 15.7 & 17.5 \\
\hline Height $(\mathrm{cm})$ & 84 & 91 & 132.6 & 145 & 149.8 \\
\hline Height SDS & -3.6 & -4.38 & -2.4 & -2.95 & -2.23 \\
\hline Weight (kg) & 11.4 & 13.7 & 25.2 & 35.8 & 41 \\
\hline Tanner stage & $\begin{array}{l}\text { Telarche } 1 \\
\text { Pubarche } 1\end{array}$ & $\begin{array}{l}\text { Telarche } 1 \\
\text { Pubarche } 1\end{array}$ & $\begin{array}{l}\text { Telarche } 1 \\
\text { Pubarche } 1\end{array}$ & $\begin{array}{l}\text { Telarche } 1 \\
\text { Pubarche } 1\end{array}$ & $\begin{array}{l}\text { Telarche } 3 \\
\text { Pubarche } 2\end{array}$ \\
\hline $\begin{array}{l}\text { Laboratory } \\
\text { values }\end{array}$ & $\begin{array}{l}\text { Hemogram, thyroid } \\
\text { functions, electrolytes, } \\
\text { renal functions and } \\
\text { liver function tests were } \\
\text { normal }\end{array}$ & $\begin{array}{l}\text { IGF-1: } 18.4 \mathrm{ng} / \mathrm{mL} \\
\text { Peak GH: } 6.1 \mathrm{ng} / \mathrm{mL} \\
\text { (L-Dopa) and } 3.3 \mathrm{ng} / \\
\text { mL (ITT) }\end{array}$ & $\begin{array}{l}\text { FBG: } 136 \mathrm{mg} / \mathrm{dL} \\
\text { Fasting C-peptide: } 1.29 \mathrm{ng} / \mathrm{mL} \\
\text { Fasting insulin: } 7.2 \mathrm{mIU} / \mathrm{mL} \\
\text { OGTT: BG at } 120^{\prime}: 242 \mathrm{mg} / \mathrm{dL} \text {, } \\
\text { insulin at } 120^{\prime}: 47 \mathrm{mIU} / \mathrm{mL} \text { ) }\end{array}$ & $\begin{array}{l}\text { E2: }<10 \mathrm{pg} / \mathrm{mL} \\
\mathrm{LH}: 9.5 \mathrm{mIU} / \mathrm{mL} \\
\text { FSH: } 18.4 \mathrm{mIU} / \mathrm{mL} \\
\text { AMH: } 0.07 \mathrm{pmol} / \mathrm{L}\end{array}$ & \\
\hline
\end{tabular}

LH: luteinizing hormone, FSH: follicle stimulating hormone, AMH: anti-Mullerian hormone, OGTT: oral glucose tolerance test, SDS: standard deviation score, GH: growth hormone, IGF-1: insulin-like growth factor-1, ITT: insulin tolerance test, FBG: fasting blood glucose, BG: blood glucose 
based on American College of Medical Genetics and Genomics variant classification guidelines, was considered to be a pathogenic variant. The parents could not be studied for any possible genetic mutations, and therefore, their carrier status could not be confirmed.

\section{Discussion}

There have been a total of 19 reported cases of TRMT10A syndrome within 12 families, with the first case reported by Igoillo-Esteve et al. (2) in 2013 (Table 2) $(3,4,5,6,8,10,11,12,13,14)$. All patients, except for those cases reported by Zung et al. (4), had homozygous or compound heterozygous loss of function mutations within the TRMT10A gene. The cases of Zung et al. (4) also had a large deletion within the chromosomal region $4 \mathrm{q} 23$ which included nine genes, one of them being TRMT10A.

The current case was the first case in our country with TRMT10A syndrome. She was born SGA with distinctive features including microcephaly, intellectual impairment and epilepsy. At 3.65 years of age, hypoglycemia and severe short stature related to GH deficiency were detected. At 11.41 years of age, she had an incidental diagnosis of nonautoimmune diabetes. Before the development of diabetes, fasting hypoglycemia occurred. A pubertal disorder resembling primary ovarian failure was also detected at the age of 15.7 years.

Microcephaly and intellectual disability were observed in all cases. Epileptic seizures were also observed frequently in some cases. Eight out of 11 cases with cranial imaging results were found to be normal $(2,3,4,5,6,10,12,13)$. Some minor clinical findings such as low anterior hair line, deep-set eyes with mild hypotelorism, shortened forehead and buffalo hump were also reported, which are similar to our case. In addition to findings of central nervous system involvement, in our patient, an arachnoid cyst was detected, which we believe to be an incidental finding as they are common in the population (2.6\%) (15).

Growth was retarded in most of the cases. However, detailed information about the height SDS, body proportions and GH axis evaluations of patients was not fully available. IgoilloEsteve et al. (2) reported the final adult height of their patients as being short (Table 2). The height of those cases by reported Gillis et al. (3) were below the third percentile with no given height z-scores. On the other hand, similar to our case, the height z-score of the case reported by Zung et al. (4) indicated serious short stature (-4.24). In addition, only one case had an evaluation of GH secretion (8). This case which was reported by Stern et al. (8) had short stature, low growth velocity and delayed bone age.
After $\mathrm{GH}$ stimulations tests were performed, peak GH was found to be $7.3 \mathrm{mcg} / \mathrm{l}$ on clonidine and $1.8 \mathrm{mcg} / \mathrm{l}$ on Arginine stimulations. The MRI of the patient was found to be normal. GH replacement therapy could not be given. Our case was diagnosed with GH deficiency before the TRMT10A mutation was identified. Low growth velocity, inadequate responses to $\mathrm{GH}$ stimulation tests, retarded bone age and small hypophysis were all consistent with the diagnosis of $\mathrm{GH}$ deficiency. Moreover, the patient responded well to rhGH treatment as her growth velocity increased. These features suggest that the GH deficiency in our patient was caused by the TRMT10A mutation, although it is difficult to conclude precisely and more cases are needed to confirm if this is indeed a feature of TRMT10A syndrome. As tRNAs are crucial for cellular function and TRMT10A deficiency causes tRNA modification, all cells expressing TRMT10A would be affected. It is known that many cells in the brain including the hypothalamus and pituitary glands express TRMT10A protein. So hypothalamohypophysial functions in terms of GH secretion could be affected by TRMT10A deficiency.

Our case displayed the characteristics of hypergonadotropic hypogonadism. Puberty had not begun spontaneously when the patient was seen at 15.7 years of age. Laboratory values and pelvic ultrasound were compatible with ovarian failure. Even though pubertal delay in TRMT10A deficiency has been mentioned before, no detailed description of this was explained except by Zung et al. $(3,4,5)$. Zung et al. (4) described the unusual pubertal progression of a female patient who showed intermittent progression with high gonadotropin levels during pubertal arrest and normal/ low gonadotropin levels with estradiol elevation following pubertal progression periods. They concluded that this intermittent progression of puberty was related to the occurrence of transient episodes of gonadal failure and successive episodes of gonadal recovery. There were no detailed descriptions of pubertal progress in the other two cases.

Although gonadal expression of TRMT10A has not been demonstrated to date, this syndrome may lead to primary gonadal failure. We cannot be certain that primary ovarian failure is caused by the loss of TRMT10A and further validation in future cases will be required in order to be certain.

The most interesting characteristics of these cases could be the abnormalities in glucose metabolism. Eight of the reported cases with TRMT10A syndrome had diabetes. The age at diagnosis for diabetes varied between 9 and 28 years. C-peptide was detectable in all diabetic patients. Five patients were treated with insulin, three with metformin, and one case with insulin plus metformin $(2,3,4,5,8,14)$. 
Table 2. Characteristics of patients with TRMT10A mutations reported in the literature

$\begin{array}{llll}\text { Igoillo-Esteve et al. } & \text { Gillis et al. } & \text { Zung et al. } & \text { Yew et al. } \\ \text { (2), } 2013 & \text { (3), } 2014 & \text { (4), 2015 } & \text { (5), 2016 }\end{array}$

\begin{tabular}{|c|c|c|c|c|c|c|c|c|}
\hline Case no & 1 & 2 & 3 & 4 & 5 & 6 & 7 & 8 \\
\hline $\begin{array}{l}\text { TRMT10A } \\
\text { Mutation } \\
\text { (based on } \\
\text { RefSeq } \\
\text { NM_152292.5) }\end{array}$ & $\begin{array}{l}\text { c. } 379 \mathrm{G}>\mathrm{A}, \\
\text { p.Arg } 127^{*}\end{array}$ & $\begin{array}{l}\text { c. } 379 \mathrm{G}>\mathrm{A}, \\
\text { p.Arg1 } 127^{*}\end{array}$ & $\begin{array}{l}\text { c. } 379 \mathrm{G}>\mathrm{A}, \\
\text { p.Arg1 } 127^{*}\end{array}$ & $\begin{array}{l}\text { c.616G > A, } \\
\text { p.Gly206Arg }\end{array}$ & $\begin{array}{l}\text { c.616G > A, } \\
\text { p.Gly206Arg }\end{array}$ & $\begin{array}{l}\text { c. } 616 \mathrm{G}>\mathrm{A}, \\
\text { p.Gly206Arg }\end{array}$ & $4 q 23$ deletion & c. $79 \mathrm{G}>\mathrm{T}$, p.Glu $27^{*}$ \\
\hline Sex & $\mathrm{F}$ & $\mathrm{F}$ & M & $\mathrm{F}$ & M & M & $\mathrm{F}$ & $\mathrm{F}$ \\
\hline Short stature & Yes & Yes & Yes & Yes & Yes & Yes & Yes & No \\
\hline $\begin{array}{l}\text { Delayed } \\
\text { puberty }\end{array}$ & $\mathrm{NR}^{*}$ & NR & NR & Yes & NR & NR & Yes & No \\
\hline $\begin{array}{l}\text { Diabetes } \\
\text { mellitus/age } \\
\text { of diagnosis }\end{array}$ & $\begin{array}{l}\text { Yes/ } \\
22 \mathrm{y}\end{array}$ & $\begin{array}{l}\text { Yes/ } \\
19 \mathrm{y}\end{array}$ & $\begin{array}{l}\text { Yes/ } \\
14 \mathrm{y}\end{array}$ & $\begin{array}{l}\text { Yes/ } \\
9 \mathrm{y}\end{array}$ & - & - & $\begin{array}{l}\text { Yes/ } \\
15 \mathrm{y}\end{array}$ & $\begin{array}{l}\text { Yes/ } \\
24 y\end{array}$ \\
\hline $\begin{array}{l}\text { Diabetes } \\
\text { treatment }\end{array}$ & Ins** & Ins & Ins & Diet & - & - & Ins & $\begin{array}{l}\text { Ins + } \\
\text { Met }\end{array}$ \\
\hline Hypoglycemia & NR & NR & NR & Yes & Yes & Yes & Yes & No \\
\hline $\begin{array}{l}\text { Other clinical } \\
\text { features }\end{array}$ & $\begin{array}{l}\text { Short neck, } \\
\text { wide nose, low } \\
\text { hairline, buffalo } \\
\text { hump, retraction } \\
\text { of right } 5^{\text {th }} \\
\text { toe, scoliosis, } \\
\text { joint laxity, } \\
\text { microcephaly, } \\
\text { epilepsy }\end{array}$ & Microcephaly & Microcephaly & $\begin{array}{l}\text { Microcephaly, } \\
\text { epilepsy }\end{array}$ & $\begin{array}{l}\text { Microcephaly, } \\
\text { epilepsy }\end{array}$ & $\begin{array}{l}\text { Microcephaly, } \\
\text { epilepsy }\end{array}$ & $\begin{array}{l}\text { Small face, } \\
\text { clinodactyly, } \\
\text { sensorineural } \\
\text { hearing } \\
\text { impairment, } \\
\text { microcephaly }\end{array}$ & $\begin{array}{l}\text { Buffalo hump, } \\
\text { Microcephaly, } \\
\text { epilepsy }\end{array}$ \\
\hline
\end{tabular}

$\mathrm{NR}^{*}$ : not reported, Ins ${ }^{* *}$ : insulin, Met ${ }^{* *}:$ metformin, F: female, M: male, y: year

TRMT10A syndrome patients have persistent insulin secretion similar to Maturity Onset Diabetes of the Young (MODY) and contrary to type 1 diabetes. The clinical picture of diabetes was usually slow onset as seen in our case. Since diabetes appeared at 11.4 years of age, the patient responded well to metformin and subsequently $\mathrm{HbA1C}$ decreased. This suggested that there was a persistence of endogenous insulin. Our case highlighted that TMRT10A mutations are an important cause of non-obesity related and non-insulin dependent diabetes in childhood. Genetic testing for TRMT10A along with common MODY genes should be undertaken in patients with non-insulin treated diabetes, particularly in the presence of other extrapancreatic features.

Interestingly, loss of function mutations in TRMT10A can cause hyperinsulinism (HI) as well as diabetes in the same subject $(3,4,14)$. Fasting hypoglycemia developed before diabetes in two cases $(3,4)$. Another two cases within the family reported by Gillis et al. (3) only had fasting hypoglycemia and high fasting insulin was also detected in those cases (4). Lin et al. (14) reported a diabetic child with high insulin and C-peptide levels to OGTT. They suggested that according to the OGTT results, insulin resistance appeared to be the dominant pathophysiological mechanism in their patient. In their case, spontaneous mild hypoglycemia was also detected.

Childhood onset hypoglycemia prior to developing diabetes has been reported in HNF4A MODY. The exact mechanism of this bidirectional glucose variability is unknown $(16,17)$. Our patient had an incidental finding of low BG with no clear symptoms. The previously reported case by Zung et al. (4) had HI between 2.5 and 7.4 years of age and developed diabetes at 15.2 years of age.

TRMT10A deficiency leads to oxidative stress mediated apoptosis in the pancreatic beta cells. In an elegant study, Cosentino et al. (7) showed that tRNA guanosin 9 hypomethylation induces tRNAGln fragmentation. These fragments mediated TRMT10A-deficient beta cell death. The clinical hallmark of TRMT10A related diabetes is slow onset with non-autoimmunity.

Our knowledge and understanding of TRMT10A syndrome is increasing rapidly, despite it being recently described. However, some questions remain unanswered with regards to early hypoglycemic events and its characteristics of pubertal delay. 


\section{Narayanan et al.}

(6), 2015

\section{Boonsawat Duerinckx et $\mathrm{Hu}$ et}

et al. (10), 2019 al. (11), 2020 al. (12),

2019
Reuter et al. Lin et al (14), Stern et al. Presented

(13), $2017 \quad 2020$

(8), 2021 case

\begin{tabular}{|c|c|c|c|c|c|c|c|c|c|}
\hline 9 & 10 & 11 & 12 & 13 & $14 / 15$ & $16 / 17$ & 18 & 19 & 20 \\
\hline $\begin{array}{l}\text { c. } 79 \mathrm{G}>\mathrm{T} \text {, } \\
\text { p.Glu } 27^{*}\end{array}$ & $\begin{array}{l}\text { c. } 277 \mathrm{C}>\mathrm{T} \\
(\text { p.Arg93*) } \\
\text { c. } 397 \mathrm{C}>\mathrm{T} \\
\left(\text { p.Arg } 133^{*}\right)\end{array}$ & $\begin{array}{l}\text { c. } 277 \mathrm{C}>\mathrm{T} \\
(\text { p.Arg93*) } \\
\text { c. } 397 \mathrm{C}>\mathrm{T} \\
(\text { p.Arg133*) }\end{array}$ & $\begin{array}{l}\text { c. } 379 \mathrm{C}>\mathrm{T}, \\
\text { p.Arg } 127^{*}\end{array}$ & $\begin{array}{l}\text { c. } 379 \mathrm{C}>\mathrm{T}, \\
\text { p.R127* }\end{array}$ & $\begin{array}{l}\text { c. } 370>A \\
\text { p.Q124K }\end{array}$ & $\begin{array}{l}\text { c. } 348 \mathrm{G}>\mathrm{C} \\
\text { p.K116N }\end{array}$ & c. $496-1 \mathrm{G}>\mathrm{A})$ & $\begin{array}{l}\text { c. } 616 \mathrm{G}>\mathrm{A} \text {, } \\
\text { p.G206R }\end{array}$ & $\begin{array}{l}\text { c. } 379 \mathrm{C}>\mathrm{T}, \\
\text { p. }\left(\operatorname{Arg} 127^{*}\right)\end{array}$ \\
\hline M & $\mathrm{F}$ & M & NR & NR & NR/NR & $\mathrm{M} / \mathrm{M}$ & NR & $\mathrm{F}$ & $\mathrm{F}$ \\
\hline No & NR & Yes & Yes & NR & NR/NR & Yes /yes & Yes & Yes & Yes \\
\hline Yes & NR & NR & NR & NR & NR/NR & NR/NR & NR & No & Yes \\
\hline $\begin{array}{l}\text { Yes/ } \\
28 \mathrm{y}\end{array}$ & - & - & NR & NR & NR/NR & NR/NR & $\begin{array}{l}\text { Yes/ } \\
\text { NR }\end{array}$ & $\begin{array}{l}\text { Yes/ } \\
11 \mathrm{y}\end{array}$ & $\begin{array}{l}\text { Yes/ } \\
11.4 \mathrm{y}\end{array}$ \\
\hline Met $^{* * *}$ & - & - & - & - & - & - & Met & Ins & Met \\
\hline No & NR & NR & NR & NR & NR/NR & NR/NR & NR & NR & Yes \\
\hline $\begin{array}{l}\text { Microcephaly, } \\
\text { epilepsy }\end{array}$ & $\begin{array}{l}\text { low anterior } \\
\text { hair line, } \\
\text { deep set eyes } \\
\text { with mild } \\
\text { hypotelorism, } \\
\text { shortened }\end{array}$ & $\begin{array}{l}\text { low anterior } \\
\text { hair line, } \\
\text { deep set eyes } \\
\text { with mild } \\
\text { hypotelorism, } \\
\text { microcephaly, }\end{array}$ & & & & $\begin{array}{l}\text { Hypotonia, } \\
\text { uvula bifida, } \\
\text { mild turuncal } \\
\text { adiposit, } \\
\text { microcephaly, } \\
\text { epilepsy }\end{array}$ & Microcephaly & $\begin{array}{l}\text { Microcephaly } \\
\text { in both }\end{array}$ & $\begin{array}{l}\text { Small face } \\
\text { and deeply } \\
\text { located eyes, } \\
\text { microcephaly, } \\
\text { epilepsy }\end{array}$ \\
\hline
\end{tabular}

Patel, Merih Berberoğlu, Analysis or Interpretation: Zeynep Şıklar, Kevin Colclough, Kashyap A. Patel, Merih Berberoğlu, Literature Search: Zeynep Şıklar, Tuğba Kontbay, Writing: Zeynep Ssıklar, Kevin Colclough, Kashyap A. Patel, Merih Berberoğlu.

Financial Disclosure: Genetic testing was conducted as a part of the Wellcome Trust grant to Kashyap Patel $(110082 / \mathrm{Z} / 15 / \mathrm{Z})$.

\section{References}

1. Hattersley AT, Patel KA. Precision diabetes: learning from monogenic diabetes. Diabetologia 2017;60:769-777. Epub 2017 Mar 17

2. Igoillo-Esteve M, Genin A, Lambert N, Désir J, Pirson I, Abdulkarim B, Simonis N, Drielsma A, Marselli L, Marchetti P, Vanderhaeghen P, Eizirik DL, Wuyts W, Julier C, Chakera AJ, Ellard S, Hattersley AT, Abramowicz M, Cnop M. tRNA methyltransferase homolog gene TRMT 10A mutation in young onset diabetes and primary microcephaly in humans. PLoS Genet 2013;9:e1003888. Epub 2013 Oct 31

3. Gillis D, Krishnamohan A, Yaacov B, Shaag A, Jackman JE, Elpeleg O. TRMT10A dysfunction is associated with abnormalities in glucose homeostasis, short stature and microcephaly. J Med Genet 2014;51:581586. Epub 2014 Jul 22

4. Zung A, Kori M, Burundukov E, Ben-Yosef T, Tatoor Y, Granot E. Homozygous deletion of TRMT10A as part of a contiguous gene deletion in a syndrome of failure to thrive, delayed puberty, intellectual 
disability and diabetes mellitus. Am J Med Genet A 2015;167A:31673173. Epub 2015 Aug 22

5. Yew TW, McCreight L, Colclough K, Ellard S, Pearson ER. tRNA methyltransferase homologue gene TRMT10A mutation in young adultonset diabetes with intellectual disability, microcephaly and epilepsy. Diabet Med 2016;33:21-25

6. Narayanan M, Ramsey $\mathrm{K}$, Grebe $\mathrm{T}$, Schrauwen I, Szelinger S, Huentelman M, Craig D, Narayanan V; C4RCD Research Group. Case Report: Compound heterozygous nonsense mutations in TRMT10A are associated with microcephaly, delayed development, and periventricular white matter hyperintensities. F1000Res 2015;4:912.

7. Cosentino C, Toivonen S, Diaz Villamil E, Atta M, Ravanat JL, Demine S, Schiavo AA, Pachera N, Deglasse JP, Jonas JC, Balboa D, Otonkoski T, Pearson ER, Marchetti P, Eizirik DL, Cnop M, Igoillo-Esteve M. Pancreatic $\beta$-cell tRNA hypomethylation and fragmentation link TRMT10A deficiency with diabetes. Nucleic Acids Res 2018;46:1030210318.

8. Stern E, Vivante A, Barel O, Levy-Shraga Y. TRMT10A mutation in achild with diabetes, short stature, microcephaly and hypoplastic kidneys. J Clin Res Pediatr Endocrinol 2022;14:227-232. Epub 2021 Jan 15

9. Bozzola M. Meazza C. Growth hormone deficiency: diagnosis and therapy in children. Expert Rev Endocrinol Metab 2010;5:273-284.

10. Boonsawat P, Joset P, Steindl K, Oneda B, Gogoll L, Azzarello-Burri S, Sheth F, Datar C, Verma IC, Puri RD, Zollino M, Bachmann-Gagescu R, Niedrist D, Papik M, Figueiro-Silva J, Masood R, Zweier M, Kraemer D, Lincoln S, Rodan L; Undiagnosed Diseases Network (UDN); Passemard S, Drunat S, Verloes A, Horn AHC, Sticht H, Steinfeld R, Plecko B, Latal B, Jenni O, Asadollahi R, Rauch A. Elucidation of the phenotypic spectrum and genetic landscape in primary and secondary microcephaly. Genet Med 2019;21:2043-2058. Epub 2019 Mar

11. Duerinckx S, Jacquemin V, Drunat S, Vial Y, Passemard S, Perazzolo C, Massart A, Soblet J, Racapé J, Desmyter L, Badoer C, Papadimitriou $\mathrm{S}$, Le Borgne YA, Lefort A, Libert F, De Maertelaer V, Rooman M, Costagliola S, Verloes A, Lenaerts T, Pirson I, Abramowicz M. Digenic inheritance of human primary microcephaly delineates centrosomal and non-centrosomal pathways. Hum Mutat 2020;41:512-524. Epub 2019 Nov 27
12. Hu H, Kahrizi K, Musante L, Fattahi Z, Herwig R, Hosseini M, Oppitz C, Abedini SS, Suckow V, Larti F, Beheshtian M, Lipkowitz B, Akhtarkhavari T, Mehvari S, Otto S, Mohseni M, Arzhangi S, Jamali P, Mojahedi F, Taghdiri M, Papari E, Soltani Banavandi MJ, Akbari S, Tonekaboni SH, Dehghani H, Ebrahimpour MR, Bader I, Davarnia B, Cohen M, Khodaei H, Albrecht B, Azimi S, Zirn B, Bastami M, Wieczorek D, Bahrami G, Keleman K, Vahid LN, Tzschach A, Gärtner J, Gillessen-Kaesbach G, Varaghchi JR, Timmermann B, Pourfatemi F, Jankhah A, Chen W, Nikuei P, Kalscheuer VM, Oladnabi M, Wienker TF, Ropers HH, Najmabadi $\mathrm{H}$. Genetics of intellectual disability in consanguineous families. Mol Psychiatry 2019;24:1027-1039. Epub 2018 Jan 4

13. Reuter MS, Tawamie H, Buchert R, Hosny Gebril O, Froukh T, Thiel C, Uebe S, Ekici AB, Krumbiegel M, Zweier C, Hoyer J, Eberlein K, Bauer J, Scheller U, Strom TM, Hoffjan S, Abdelraouf ER, Meguid NA, Abboud A, Al Khateeb MA, Fakher M, Hamdan S, Ismael A, Muhammad S, Abdallah E, Sticht H, Wieczorek D, Reis A, Abou Jamra R. Diagnostic Yield and Novel Candidate Genes by Exome Sequencing in 152 Consanguineous Families With Neurodevelopmental Disorders. JAMA Psychiatry 2017;74:293-299.

14. Lin H, Zhou X, Chen X, Huang K, Wu W, Fu J, Li Y, Polychronakos C, Dong GP. tRNA methyltransferase 10 homologue A (TRMT10A) mutation in a Chinese patient with diabetes, insulin resistance, intellectual deficiency and microcephaly. BMJ Open Diabetes Res Care 2020;8:e001601.

15. Al-Holou WN, Yew AY, Boomsaad ZE, Garton HJ, Muraszko KM, Maher CO. Prevalence and natural history of arachnoid cysts in children. J Neurosurg Pediatr 2010;5:578-585.

16. Colclough K, Bellanne-Chantelot C, Saint-Martin C, Flanagan SE, Ellard $\mathrm{S}$. Mutations in the genes encoding the transcription factors hepatocyte nuclear factor 1 alpha and 4 alpha in maturity-onset diabetes of the young and hyperinsulinemic hypoglycemia. Hum Mutat 2013;34:669685. Epub 2013 Apr 2

17. Şıklar Z, de Franco E, Johnson MB, Flanagan SE, Ellard S, Ceylaner S, Boztuğ K, Doğu F, İkincioğulları A, Kuloğlu Z, Kansu A, Berberoğlu M. Monogenic Diabetes Not Caused By Mutations in Mody Genes: A Very Heterogenous Group of Diabetes. Exp Clin Endocrinol Diabetes 2018;126:612-618. Epub 2017 Nov 28 